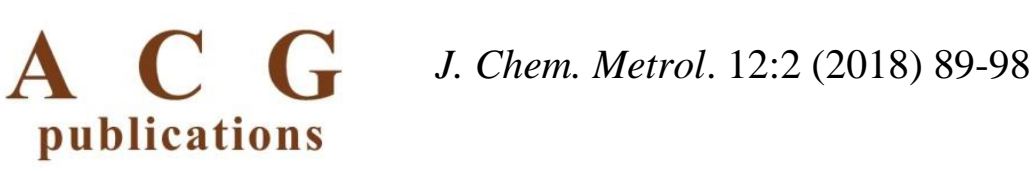

\title{
Effect of priming on thymoquinone content and in vitro plant regeneration with tissue culture of black cumin (Nigella sativa L.) seeds
}

\author{
Fereshteh Rezaei $\odot^{1}$, Selin Isik $\odot^{* 2}$, Murat Kartal $\odot^{3}$ and \\ Sinem Aslan Erdem ${ }^{4}$
}

\author{
${ }^{1}$ Department of Field Crops, Faculty of Agriculture, Ankara University, Dışkapı, Ankara, Türkiye \\ ${ }^{2}$ Department of Analytical Chemistry, Faculty of Pharmacy, Near East University, 99138 Nicosia, \\ Turkish Republic of Northern Cyprus, Mersin 10, Türkiye \\ ${ }^{3}$ Center of Education, Practice and Research in Phytotherapy, Bezmialem Vakif University,34093, \\ Fatih, Istanbul, Türkiye \\ ${ }^{4}$ Department of Pharmacognosy, Faculty of Pharmacy, Ankara University, Ankara, Türkiye
}

(Received September 25, 2018; Revised November 21, 2018; Accepted November 22, 2018)

\begin{abstract}
The aim of this study is to analyze the changes on thymoquinone content, which is the major constituent of black cumin (Nigella sativa L.) seeds, by using priming methods. For the priming studies, seeds placed in distilled water (18 - 20 hours), PEG (Polyethylene glycol 10\%, 20\%) and mannitol (4\% and 6\%) for 20 hours and subsequently dried for 24 hours on blotting paper at room temperature $\left(24{ }^{\circ} \mathrm{C} \pm 1{ }^{\circ} \mathrm{C}\right)$. The best priming results were obtained in the $4 \%$ of mannitol treatment. Control (not primed) Nigella seeds and $4 \%$ of mannitol primed seeds were planted in both greenhouse and farm conditions. Seed extracts were analyzed with HPLC to compare the amount of thymoquinone. The results reveal that seed priming with $4 \%$ of mannitol increases the amount of thymoquinone in Nigella sativa. In addition, the effects of plant growth hormones on callus regeneration of these primed seeds were investigated herein.
\end{abstract}

Keywords: Black cumin; HPLC; Nigella sativa; priming; thymoquinone; tissue culture. (C) 2018 ACG Publications. All rights reserved.

\section{Introduction}

The seeds of Nigella sativa L., commonly known as black cumin, black seed, "Habbat ul Sawda", "çörek otu" and "siyah kimyon", have been extensively researched regarding their medicinal and economic status, particularly in recent years. It is well-known and grows in many parts of Turkey $[1,2]$.

Millions of people in the Mediterranean region including Turkey use black cumin seeds and seed oils for traditional medicine. The pharmacological properties that have been reported are: antiinflammatory effect [3-5], cytotoxic effect [6-9], antihistaminic effect [10], antimicrobial effect $[11,12]$, antioxidant effect [13-15], effects on cancer and the immune system [16,17] anti-inflammatory effect [18], anti-allergic effect [19], and antimicrobial effect [20]. One of the most active constituents of essential oil (0.4-0.45\%) is thymoquinone (TQ), which has different beneficial properties [21] such as an antioxidant effect [22], antiulcer effect [23], and anti-inflammatory effect [3]. It is possible to minimize the incurred bio-hazards if germination and seedling emergence is accelerated by priming, which means that germination is allowed until the radicle emerges from the seed. This process was

*Corresponding author E-Mail: selin_isikk@hotmail.com 
described for the first time by Anwar Khan and includes seed soaking in tap/distilled water or osmotic solution, etc. In this process, seeds are partially or completely soaked, and are then dried so that the germination processes can begin but radical emergence does not occur. With this treatment, it is possible to obtain better biological functions in terms of germination and seedling establishment [24] during the lag phase (second stage of seed priming) with increased RNA and protein synthesis [25], faster embryo growth [26] and reduced leakage of metabolites [27]. When the seeds are germinated or reach the postgerminated/seedling stage and are exposed to abiotic stress (particularly oxidative stress), they release different chemical compounds (such as $\mathrm{O}_{2}$, singlet oxygen $(\mathrm{O})$, hydrogen peroxide $\left(\mathrm{H}_{2} \mathrm{O}_{2}\right)$, free $\mathrm{OH}$ radicals) and reactive oxygen species (ROS) molecules [28,29]. However, if these substances exceed their threshold levels, they could have deleterious effects on cells. At this time, plants activate their defensive mechanisms in the chloroplasts, cytosol, mitochondria, paroxysms and apoplast [30,31]. For quantifying thymoquinone in Nigella sativa seed oil, HPLC is utilized to quantify the thymoquinone, which is one of the active constituents in the seed oil and seed extracts of Nigella sativa.

This study was conducted with the aim of observing the effects of seed priming on the investigated traits of Nigella sativa seeds, in order to determine whether there is a relationship between priming with different doses of mannitol and the amount of thymoquinone.

\section{Materials and Methods}

\subsection{Plant material, preparations and treatments}

\subsubsection{Priming conditions}

Distilled water, PEG (10\% and 20\%) and mannitol (4\% and 6\%) treatments were used for priming. Seeds were immersed fully in these solutions for 20 hours and dried on filter papers at room temperature for 24 hours. A total of 50 seeds of each treatment and non-primed (control) seeds were germinated between two filter papers $(20 \times 20 \mathrm{~cm})$ in a germinator at room temperature. Seed germination was recorded daily until 17 days after the start of the experiment. When the radicle emerged by about $2 \mathrm{~mm}$ in length, a seed was considered as germinated according to ISTA rules.

Germination percentage was determined at the end of test. The values on the $7^{\text {th }}$ day of the test were recorded for germination speed and the values on the $17^{\text {th }}$ day of the test were recorded for germination power according to ISTA rules. To determine the radicle and plumule length after the $17^{\text {th }}$ day, radicles and plumules of 10 seedlings produced in each treatment were separated from the seeds. Their lengths were measured in $\mathrm{cm}$ and weighted to calculate seedling wet weight, then dried at $80{ }^{\circ} \mathrm{C}$ for 24 hours to determine seedling dry weight. Averages for both wet and dry weights were determined as $\mathrm{mg} / \mathrm{seedling}$.

\subsubsection{Greenhouse and field experiments}

This experiment was conducted in the greenhouses of the Ankara University Faculty of Agriculture Field Crops Department during the trial period. The aim of this study was to determine the effects of priming on the thymoquinone amount in Nigella sativa. Before the experiments started, pots were filled with soil mix (soil + sand+ fertilizer). Each pot was planted with both 10 control (not primed) and primed (4\% mannitol) seeds. In order to standardize the plant amount, the number of plants in each flower pot was reduced to 5 after the output. Each flowerpot was watered equally and controlled on a daily basis.

For the field experiments, primed (4\% mannitol) seeds were dried for 24 hours at room temperature and planted with control seeds in a field in April.

\subsection{Chemicals and materials}

HPLC grade water methanol and 2-propanol (50:45:5) (Fisher Scientific, Pittsburgh, PA) were used. Millipore filtered water was obtained using a Milli-Q system (Millipore Corp., Milford, MA), Thymoquinone standard (Sigma, St. Louis, MO) was purchased and dissolved in HPLC grade methanol 
for the analysis. For tissue culture, 3\% sucrose, 0.7\% Agar (Type A, Sigma) and Magenta vessels (Sigma - Aldrich GA-7) were used.

\subsection{Seed extraction}

A total of $5 \mathrm{~g}$ powdered Nigella sativa seeds were stirred with $200 \mathrm{~mL}$ methanol for 2 hours, filtered and then evaporated by using a rotary evaporator. The residual was dissolved gradually with methanol and completed to $50 \mathrm{~mL}$ with methanol.

\subsection{Oil extraction}

$20 \mu \mathrm{L}$ of black cumin oil was applied to the SPE (Solid phase extraction) C18 cartridge, eluted by $2 \times 400 \mu \mathrm{L}$ methanol.

\subsection{HPLC conditions}

An HPLC system composed of a model Agilent Technologies 1200 series was used including a binary pump, vacuum degasser, auto sampler, diode array detector. Column: Eclipse XDB-C18 column $(150 \mathrm{~mm} \times 4.6 \mathrm{~mm}, 5 \mu \mathrm{m})$. An isocratic mobile phase was used: a water - methanol - 2-propanol (50:45:5) mixture was used for separation at a flow rate of $0.9 \mathrm{~mL} \mathrm{~min}^{-1}$. Analysis time was $28 \mathrm{~min}$. and the detection wavelength was set at $254 \mathrm{~nm}$. The injection volume was $10 \mu \mathrm{L}$ for each sample and standard solution. Concentration calculations regarding the quantitative analysis were performed with external standardization by measurement of peak area values. This method was modified from Ghosheh et al's study [33].

\subsection{In vitro plant regeneration experiments}

\subsubsection{Tissue culture medium}

For tissue culture experiments, MS (Murashige and Skoog) mineral salt and vitamins, 3\% sucrose and $0.7 \%$ agar (Type A, Sigma) were used for plant growth medium. The $\mathrm{pH}$ of the mediums was arranged to $5.6-5.8$ by using $1 \mathrm{~N} \mathrm{HCl}$ or $1 \mathrm{~N} \mathrm{NaOH}$. They were sterilized under $118 \mathrm{kPa}$ pressure at $121{ }^{\circ} \mathrm{C}$ for 20 minutes. Hypocotyl, cotyledon and cotyledon node explants of 7-10 day old plants from sterilized seeds were used for callus reproduction.

\subsubsection{Plant regeneration}

For investigating the effect of plant growth hormones on callus reproduction, different hormone combinations of TDZ (tidiazuron) $(0.25,0.5,0.75 \mathrm{mg} / \mathrm{L})$, Kinetin $(0.5,0.75$ and $1 \mathrm{mg} / \mathrm{L})$ and BAP (benzyl aminopurine) $(0.05,0.25,0.5$ and $1 \mathrm{mg} / \mathrm{L})$ combined with NAA (naphthalene acetic acid) (1 $\mathrm{mg} / \mathrm{L}$ ) were used on of hypocothyl, cothyledon node and cothyledon explants. After the plant regeneration experiment, obtained calluses were evaluated according to the shoots and shoot lengths and the shoots were placed individually into various rooting environments (Figure 1).

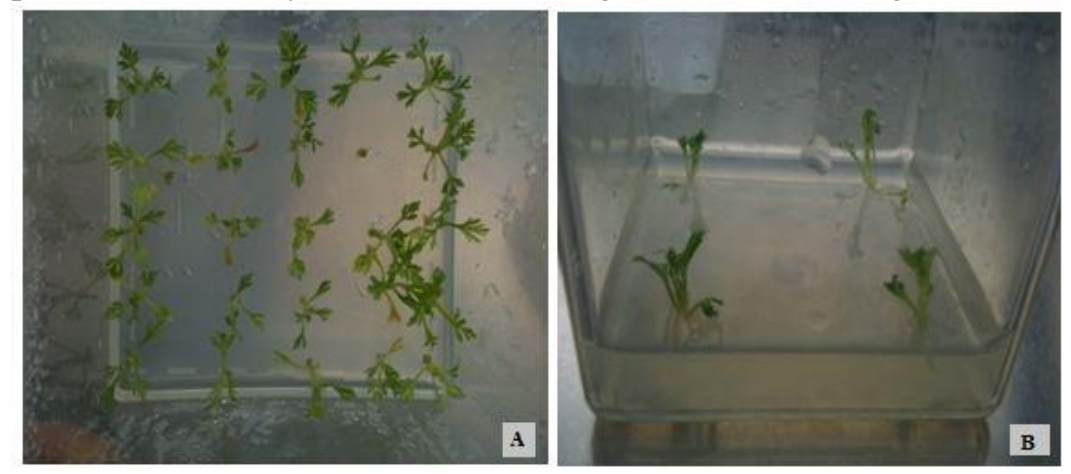

Figure 1. Rooting stage of the shoots which obtained from cotyledon node explants at the MS plant growth medium includes $0.5 \mathrm{mg} / \mathrm{L}$ Kinetin $(\mathbf{A})$ and $0.75 \mathrm{mg} / \mathrm{L}$ Kinetin $(\mathbf{B})$. 


\section{Results and Discussion}

\subsection{Results of priming application}

The values from the $7^{\text {th }}$ day of the test were recorded for germination speed, while the values from the $17^{\text {th }}$ day of the test were recorded for germination power and calculated with the ISTA rules by percentage as shown in Table 1 . The highest and lowest results were obtained from $4 \%$ mannitol primed seeds (98\%) and control (70\%) seeds, respectively.

The results of the plumule and radicle wet and dry weights were calculated by using the Duncan test, as shown in Table 1.

Table 1. The results of plumule and radicle wet and dry weights and lengths

\begin{tabular}{|c|c|c|c|c|c|c|c|c|}
\hline $\begin{array}{c}\text { Priming } \\
\text { medias }\end{array}$ & GS (\%) & GP $(\%)$ & PL (cm) & $\mathbf{R L}(\mathbf{c m})$ & $\mathbf{P W W}^{\Psi}$ & $\mathbf{P D W}^{\Psi}$ & RWW & $\mathbf{R D W}^{\Psi}$ \\
\hline $\begin{array}{c}4 \% \\
\text { Mannitol }\end{array}$ & 98 & 98 & $4.267 \mathrm{a}$ & $7.023 \mathrm{a}$ & $0.02160 \mathrm{a}$ & $0.001467 \mathrm{a}$ & $0.01047 \mathrm{a}$ & $0.0007867 \mathrm{a}$ \\
\hline $\begin{array}{c}6 \% \\
\text { Mannitol }\end{array}$ & 96 & 98 & $3.330 \mathrm{~b}$ & $5.067 \mathrm{c}$ & $0.01900 \mathrm{ab}$ & $0.001333 \mathrm{ab}$ & $0.009200 \mathrm{a}$ & $0.0006600 \mathrm{~b}$ \\
\hline PEG $10 \%$ & 80 & 95 & $3.010 \mathrm{~b}$ & $6.010 \mathrm{~b}$ & $0.01637 \mathrm{~b}$ & $0.001100 \mathrm{~b}$ & $0.007933 a b$ & $0.0005300 \mathrm{c}$ \\
\hline $\begin{array}{c}\text { PEG 20\% } \\
\text { Distilled }\end{array}$ & 80 & 95 & $2.913 \mathrm{bc}$ & $5.313 \mathrm{c}$ & $0.01657 \mathrm{~b}$ & $0.001067 \mathrm{bc}$ & $0.005000 \mathrm{ab}$ & $0.0006100 \mathrm{bc}$ \\
\hline $\begin{array}{c}\text { Water } 18 \\
\text { hours }\end{array}$ & 94 & 97 & $3.567 \mathrm{ab}$ & $6.333 \mathrm{~b}$ & $0.01610 \mathrm{~b}$ & $0.001100 \mathrm{~b}$ & $0.006767 \mathrm{ab}$ & $0.0006033 \mathrm{bc}$ \\
\hline $\begin{array}{c}\text { Distilled } \\
\text { Water } 20 \\
\text { hours }\end{array}$ & 95 & 96 & $3.533 \mathrm{ab}$ & $5.300 \mathrm{c}$ & $0.01757 \mathrm{~b}$ & $0.001133 \mathrm{~b}$ & $0.006367 \mathrm{ab}$ & $0.0005867 \mathrm{bc}$ \\
\hline Control & 70 & 90 & $2.267 \mathrm{c}$ & $2.933 \mathrm{~d}$ & $0.01533 \mathrm{~b}$ & $0.0008000 \mathrm{c}$ & $0.002367 \mathrm{~b}$ & $0.0001333 \mathrm{~d}$ \\
\hline
\end{tabular}

*GS: Germination Speed, PL: Plumule Length, RL: Radical Length, PWW: Plumule Wet Weight, PDW: Plumule Dry Weight, RWW: Radicle Wet Weight, RDW: Radicle Dry Weight

$\Psi \mathrm{mg} / \mathrm{seedling}$

\subsection{Results of HPLC analyses}

\subsubsection{Linearity}

Concentration calculations regarding the quantitative analysis performed with external standardization method by measurement of peak areas. For the calibration curve, $10 \mathrm{mg}$ standard thymoquinone dissolved in $10 \mathrm{~mL}$ methanol as a stock solution. Ten concentrations of thymoquinone standard $(0.5-750 \mathrm{ppm})$ prepared by dilution of stock solution. The calibration curve calculated applying the least-squares method to concentration versus peak area. LOD (limit of detection) and LOQ (limit of quantification) was established at 3.3 and 10 multiply of a standard deviation over slope, respectively. LOD, LOQ, $\mathrm{r}^{2}$, calibration equation value, recovery and RSD values were given at Table 3.

\subsubsection{Accuracy}

Three different concentrations of thymoquinone $(0.5,1$ and $5 \mathrm{ppm})$ were prepared and injected 3 times at three different levels as a test sample. The accuracy, defined as \% deviation of the calculated concentrations from the actual concentrations are evaluated. According to the results, accuracy found as maximum $1.6 \%$ deviation and this proves that the method is deemed to be accurate. The deviation percentage was calculated with using the following equation (1):

$\%$ Deviation $=($ Spiked Concentration - Mean Measured Concentration $) \times 100$ 


\subsubsection{Precision}

The precision of the method (within- day variations of replicate determinations) was controlled by 9 times of thymoquinone $(5 \mathrm{ppm})$ injection. The precision of the method has uttered with $0.26 \%$ RSD.

\subsubsection{Method robustness}

The robustness of the method was appraised by changing the ratios of water, methanol and 2propanol, column temperature $\left(25-35^{\circ} \mathrm{C}\right)$, and flow rate $(0.8,0.9$ and $1 \mathrm{~mL} / \mathrm{min}$.). After each change, a thymoquinone standard solution was injected three times for the determination the effects of changes on results. After the examination of chromatograms which was gained from these various conditions it can be stated that the method is quite robust.

\subsubsection{Uncertainty of analytical procedure}

The uncertainty of analytical procedure was calculated using the following equation (2):

$$
\mathrm{u}_{\text {rel.proc }}=\mathrm{RSD}_{\text {pooled }}=\sqrt{\frac{\left(\mathrm{n}_{1}-1\right) \cdot \mathrm{RSD}_{1}{ }^{2}+\left(\mathrm{n}_{2}-1\right) \cdot \mathrm{RSD}_{2}{ }^{2}+\left(\mathrm{n}_{3}-1\right) \cdot \mathrm{RSD}_{3}{ }^{2}+\ldots}{\left(\mathrm{n}_{1}-1\right)+\left(\mathrm{n}_{2}-1\right)+\ldots}}
$$

According to this formula; $\mathrm{RSD}_{1}$ is the relative standard deviation calculated for the sample at concentration $1, \mathrm{n}_{1}$ is the number of replicates for that sample, and so on. As a result of the calculations with calibration data, $\mathrm{u}_{\text {rel.proc }}$ was found as 2.82 .

\subsubsection{Nigella sativa oil extraction results}

The results of data validation show that Nigella sativa oil extract is found to contain $68.9 \mathrm{mg} / \mathrm{kg}$ of thymoquinone. The thymoquinone concentration of Nigella sativa oil extract is shown in Table 2 .

Table 2. The thymoquinone concentrations of sample extracts

\begin{tabular}{lc}
\hline Samples & Thymoquinone Content $(\mathbf{m g} / \mathbf{k g})$ \\
\hline Nigella sativa oil extract & $68.94 \pm 2.50$ \\
Control seed extract in green house & $106.04 \pm 3.9$ \\
$4 \%$ Mannitol primed seed extract in green house & $140.81 \pm 5.2$ \\
Control seed extract in field & $107.41 \pm 3.9$ \\
$4 \%$ Mannitol primed seed extract in field & $166.79 \pm 6.1$ \\
\hline
\end{tabular}

Table 3. Calibration equation, limit of detection (LOD) and limit of quantification (LOQ) values

\begin{tabular}{lcccccc}
\hline Compound & Standard curve & $\mathbf{r}^{2}$ & LOD $(\mathbf{p p m})$ & LOQ $(\mathbf{p p m})$ & $\begin{array}{c}\text { Recovery } \\
(\boldsymbol{\%})\end{array}$ & $\begin{array}{c}\text { RSD } \\
(\boldsymbol{\%})\end{array}$ \\
\hline Thymoquinone & $\mathrm{y}=57.518 \mathrm{x}+168$ & 0.9998 & 0.0303 & 0.0919 & 99.23 & 2.9 \\
\hline
\end{tabular}




\subsubsection{Greenhouse study results}

The results of the greenhouse studies show that the $4 \%$ mannitol primed seed extraction has a greater concentration of thymoquinone than the control seed (not primed) extraction (Table 2). This means that priming with $4 \%$ mannitol increases the thymoquinone amount in Nigella sativa. Chromatograms of these extracts are shown in Figure 2.
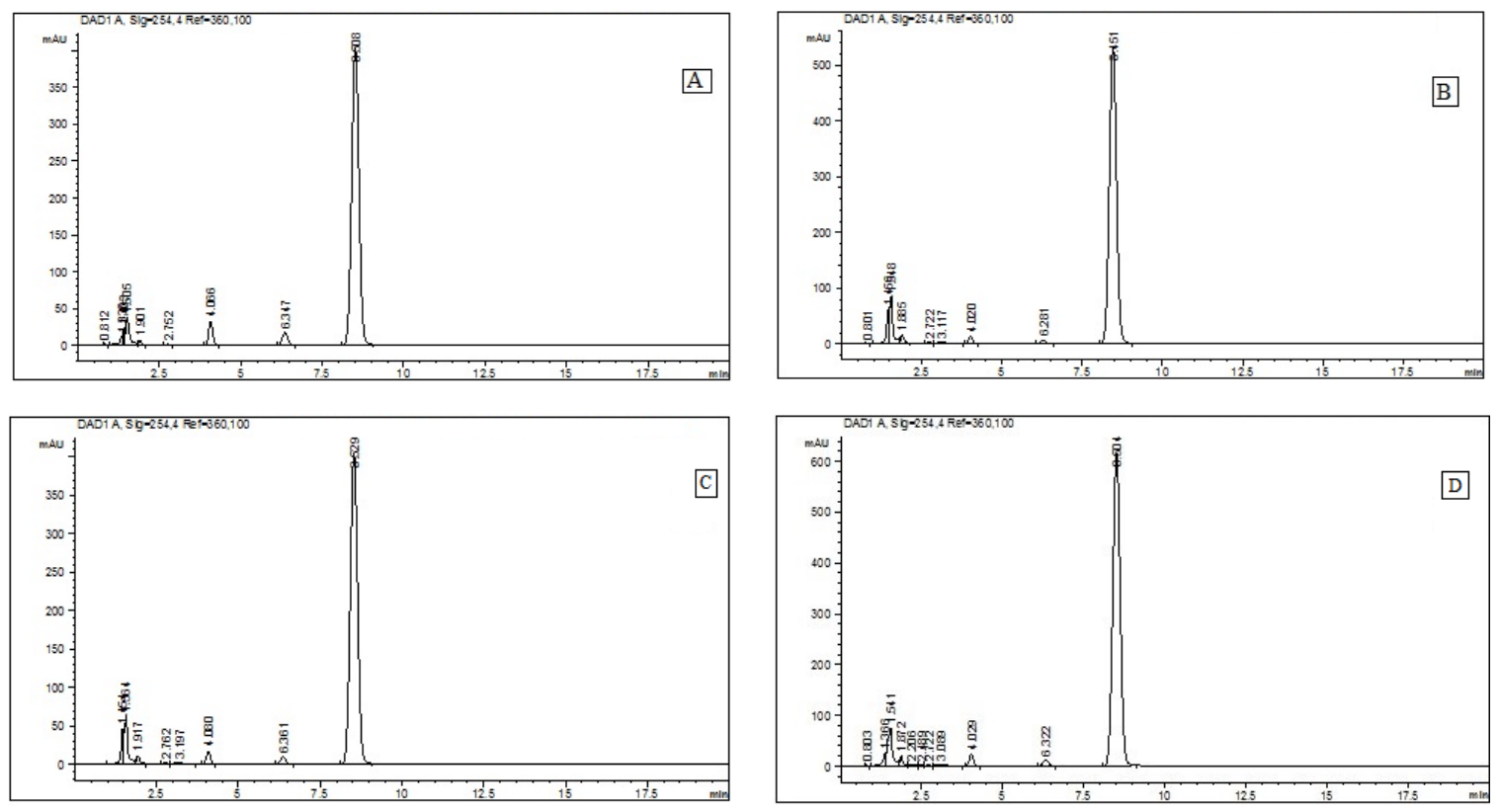

Figure 2. HPLC chromatogram of (A) control Nigella sativa seed extract in a greenhouse, (B) Nigella sativa seed extract primed with $4 \%$ of mannitol in a greenhouse, (C) control (not primed) Nigella sativa seed extract in a field and (D) Nigella sativa seed extract primed with $4 \%$ of mannitol in a field.

\subsubsection{Field study results}

The results of field studies show that there is a higher concenration of thymoquinone in seed extracts taken from the farm in comparison to the control and greenhouse results (Table 2). Chromatograms are shown in Figure 2.

Two different experiments (greenhouse and field experiments) were performed to obtain seeds extracts of Nigella sativa, and specified method with HPLC was utilized in order to evaluate the thymoquinone amount. As a result of the analyses conducted, the samples with the highest amount of thymoquinone were obtained in the seed primed with $4 \%$ mannitol in field conditions. Furthermore, the lowest amount of thymoquinone was found in control seeds that had not been primed.

A review of previous studies in the literature revealed that Ghosheh et al. [32] reported amount of thymoquinone in Nigella sativa oil about 0.052; in another study El-Alfy et al. [33] reported that the amount of thymoquinone in Nigella sativa oil was about $0.13-0.17$ by using Gas chromatography.

In another study with the aim of determining the amount of thymoquinone in seed oil, a quantity of thymoquinone between 0.008-0.01 was reported [34] . Tauseef Sultan et al. [35] the amount of thymoquinone was found to be about $201.31 \mathrm{mg} / \mathrm{kg}$ in oil. Houghton et al. [3], reported $0.2 \% \mathrm{w} / \mathrm{v}$ thymoquinone in Nigella sativa oil In another study, Lutterodt et al [36], obtained a volume of thymoquinone in black seed oil in 6 cold press ratio of between 3.48 and $8.73 \mathrm{mg} / \mathrm{g}$ oil. Additionally, Al-Saleh et al. [37] determined the amount of thymoquinone in Nigella sativa seeds collected from different regions of the Middle East and found the maximum rate of thymoquinone among the samples tested was $3098.5 \mathrm{mg} / \mathrm{kg}$ and the least was $1274.6 \mathrm{mg} / \mathrm{kg}$.

Yehualashet and Ermias conducted a study to compare the amount of thymoquinone in oil and seeds of black cumin with HPTLC and found $1.0 \%$ in seeds and 1.3\% in oil [38]. In Crina Toma et al.'s 
study, the amount of thymoquinone in Nigella sativa seeds was determined to be $1.65 \%$ by using the GC-MS method [39].

When we compare this study results with our previously conducted study, which investigated the thymoquinone content in Nigella sativa commercial seeds, seed oils and seed oil capsules [40], the thymoquinone values of seeds primed with $4 \%$ mannitol are consistent with each other.

In our study, the values we found in seed and oil are consistent with those in the literature detailed above. In addition, when we used seeds primed with $4 \%$ mannitol, the amount of thymoquinone in the seeds and oil was increased. According to the research reports, this is the first study to investigate the thymoquinone content in Nigella sativa seeds by using seed priming.

\subsection{Results of in vitro plant regeneration experiments}

For the investigation of callus percentages, shoot numbers and shoot lengths, each hormonized medium was tried on all of the explants (hypocotyl, cotyledon node and cotyledon). Some of the explants did not give any results, which may be associated with the conditioning room.

Whole medium concentration's callus percentages, shoot numbers and shoot lengths are summarized in Table 4.

Table 4. Callus rates, shoot numbers and shoot lengths of plant growth hormones which have different concentrations*.

\begin{tabular}{|c|c|c|c|c|c|c|c|c|c|c|}
\hline $\begin{array}{l}\text { Plant } \\
\text { Growth } \\
\text { Hormone }\end{array}$ & $\begin{array}{c}\text { Concentration } \\
(\mathrm{mg} / \mathrm{L})\end{array}$ & $\begin{array}{c}\text { CRCN* } \\
(\%)\end{array}$ & $\begin{array}{c}\mathrm{CRC}^{*} \\
(\%)\end{array}$ & $\underset{(\%)}{\text { CRH* }}$ & SNCN* & SNC* & SNH $^{*}$ & $\begin{array}{c}\text { LCNS* } \\
(\mathrm{cm})\end{array}$ & $\begin{array}{c}\mathbf{L C S}^{*} \\
(\mathbf{c m})\end{array}$ & $\begin{array}{r}\text { LHS }^{*} \\
(\mathbf{c m})\end{array}$ \\
\hline TDZ & $\begin{array}{c}0.25 \\
0.5 \\
0.75\end{array}$ & $\begin{array}{c}97 \\
80.3 \\
78.6\end{array}$ & $\begin{array}{c}77.3 \\
63.8 \\
58\end{array}$ & - & $\begin{array}{c}5 \\
2.4 \\
2.7\end{array}$ & $\begin{array}{c}3.3 \\
2 \\
1.7\end{array}$ & - & $\begin{array}{l}3.9 \\
2.9 \\
2.9\end{array}$ & $\begin{array}{l}4.1 \\
3.1 \\
2.6\end{array}$ & - \\
\hline Kinetin & $\begin{array}{c}0.5 \\
0.75 \\
1\end{array}$ & $\begin{array}{l}96 \\
90 \\
85\end{array}$ & - & $\begin{array}{c}20 \\
23.3 \\
45\end{array}$ & $\begin{array}{c}5.7 \\
3 \\
1.3\end{array}$ & - & $\begin{array}{c}2 \\
1.3 \\
1\end{array}$ & $\begin{array}{c}3.8 \\
3.5 \\
3\end{array}$ & - & $\begin{array}{l}3.5 \\
2.6 \\
3.4\end{array}$ \\
\hline $\begin{array}{l}\text { NAA } \\
\text { (combined } \\
\text { with } 0.05 \\
\text { mg/L } \\
\text { BAP) }\end{array}$ & $\begin{array}{c}0.25 \\
0.5 \\
0.75 \\
1\end{array}$ & $\begin{array}{c}98 \\
88 \\
82 \\
80.5\end{array}$ & - & $\begin{array}{l}90 \\
77 \\
76 \\
72\end{array}$ & $\begin{array}{c}5 \\
4 \\
3.6 \\
3.2\end{array}$ & - & $\begin{array}{c}4 \\
3.3 \\
3 \\
2.8\end{array}$ & $\begin{array}{l}- \\
- \\
-\end{array}$ & - & $\begin{array}{c}3.1 \\
3 \\
2.9 \\
2.6\end{array}$ \\
\hline
\end{tabular}

*CRCN: Callus rate of cotyledon node, CRC: Callus rate of cotyledon, CRH: Callus rate of hypocotyl, SNCN: Shoot number of cotyledon node, SNC: Shoot number of cotyledon, SNH: Shoot number of hypocotyl, LCNS: Length of cotyledon node shoots, LCS: Length of cotyledon shoots and LHS: Length of hypocotyl shoots

To the best of our knowledge, the in vitro plant regeneration of Nigella sativa has not been investigated previously with growth hormones and growth hormone combinations, which were investigated in this study. According to our results, the best callus ratio is associated with the NAA (combined with $0.05 \mathrm{mg} / \mathrm{L} \mathrm{BAP}$ ) growth hormone on cotyledon node. For future studies, the aim will be to determine the amount of thymoquinone through extraction of these obtained calluses.

\section{Conclusion}

The effect of seed priming was investigated to determine thymoquinone quantitatively by HPLC. To the best of our knowledge, this is the first study that has applied seed priming for examine the priming effect on the black cumin seed major compound thymoquinone.

Furthermore, although two different priming studies have been conducted on Nigella sativa seeds, neither of them investigated the difference in thymoquinone content. 
Increasing the thymoquinone amount by priming with $4 \%$ mannitol may be associated with an increase in the expression of the gene that produces thymoquinone, as a result of the cellular osmotic stress. Mannitol creates osmotic stress in cells and consequently, plasmolysis occurs, the plant reacts like it is in danger and ultimately increases its thymoquinone content. According to these results, it is recommended that seed priming is applied with 4\% mannitol in order to increase the amount of thymoquinone in black cumin seeds.

In this study, the results demonstrate that priming with $4 \%$ mannitol has an effect on increasing the amount of thymoquinone. In line with the obtained results, thymoquinone rich seeds can be obtained and this will increase the value of the products commercially. Through this study, a significant contribution has been made to the production of standardized herbal raw materials, which is a very important process for the pharmaceutical industry. In terms of the effect of this contribution on the pharmaceutical industry, our study has considerable importance in terms of biotechnology.

\section{Acknowledgements}

The authors are grateful for the project support of the Scientific and Technological Research Council of Turkey (TUBITAK) (2206 - Research Fellowship Program for Foreign Citizens- Post Doc. Research of Fereshteh REZAEI).

\section{Conflict of Interest}

The authors declare no conflicts of interest.

\section{ORCID}

Fereshteh Rezaei: 0000-0001-5414-2774

Selin Iş1k: 0000-0001-7601-3746

Murat Kartal: 0000-0003-3538-2769

Sinem Aslan Erdem: 0000-0003-1504-1916

\section{References}

[1] M.S. Akhtar, Z. Nasir and A.R. Abid (2003). Effect of feeding powdered Nigella sativa L seeds on poultry egg production and their suitability for human consumption, Vet. Arh. 73,181-190.

[2] I.A. Al-Saleh, G. Billedo and I.I. El-Doush (2006). Levels of selenium, dl- $\alpha$-tocopherol, dl- $\gamma$ tocopherol, all-trans-retinol, thymoquinone and thymol in different brands of Nigella sativa seeds, J. Food Compos. Anal. 19, 167-175.

[3] P.J. Houghton, R. Zarka, B. de las Heras and J.R.S. Hoult (1995). Fixed oil of Nigella sativa and derived thymoquinone inhibit eicosanoid generation in leukocytes and membrane lipid peroxidation, Planta Med. 61, 33-36.

[4] M. Mansour and S. Tornhamre (2004). Inhibition of 5-lipoxygenase and leukotriene C4 synthase in human blood cells by thymoquinone, J. Enzyme Inhib. Med. Chem. 19, 431-436.

[5] M. A. U. Khan M. K. Ashfaq H. S. Zuberi M. S. Mahmood and A. H. Gilani (2003). The in vivo antifungal activity of the aqueous extract from Nigella sativa seeds, Phytother. Res.17(2), 183-186.

[6] M.H. Islam, I.Z. Ahmad and M.T. Salman (2015). Neuroprotective effects of Nigella sativa extracts during germination on central nervous system, Pharmacogn. Mag. 11, 182- 189.

[7] S.M.K. Swamy and B.K.H. Tan (2000).Cytotoxic and immunopotentiating effects of ethanolic extract of Nigella sativa L seeds, J. Ethnopharmacol. 70, 1-7.

[8] M.I. Thabrew, R.R. Mitry, M.A. Morsy and R.D. Hughes (2005). Cytotoxic effects of a decoction of Nigella sativa, Hemidesmus indicus and Smilax glabra on human hepatoma HepG2 cells, Life Sci. 77, 1319-1330.

[9] M. Şahin, A., Yener, Z., Dagoğlu, G., Dede, S. , Oto and G. Alkan (2003). Karbontetraklorid (CCl4) ile deneysel olarak karaciğer nekrozu oluşturulan ratlarda vitamin E + selenyum ve Nigella sativa (çörekotu)'nın karaciğer yıkımını engelleyici etkileri, Turk. J. Vet. Anim. Sci. 27, 141-152.

[10] S. Chakravarty and A. Sarkar (2003). Trading Costs in Three U.S. Bond Markets, J. Fix. Income. 13, 39-48. 
[11] M. Arici, O. Sagdic and U. Gecgel (2005). Antibacterial effect of Turkish black cumin (Nigella sativa L) oils, Gras. Aceit., 56, 259-262.

[12] R. Agarwal, M.D. Kharya and R. Shrivastava (1979). Antimicrobial \& anthelmintic activities of the essential oil of Nigella sativa Linn, Ind. J. Exp. Biol. 17, 1264- 1265.

[13] A.A. Mahgoub (2003). Thymoquinone protects against experimental colitis in rats, Toxicol. Lett. 143, 133-143.

[14] M.N. Nagi, K. Alam, O.A. Badary, O.A. al-Shabanah, H.A. al-Sawaf and A.M. al-Bekairi (1999). Thymoquinone protects against carbon tetrachloride hepatotoxicity in mice via an antioxidant mechanism, IUBMB Life 47(1), 153-159

[15] M.K. Türkdoğan, H. Ozbek, Z. Yener, I. Tuncer, I. Uygan and E. Ceylan (2003). The role of Urtica dioica and Nigella sativa in the prevention of carbon tetrachloride-induced hepatotoxicity in rats, Phytother. Res. 17, 942-946.

[16] G.M. Mabrouk, S.S. Moselhy, S.F. Zohny, E.M. Ali, T.E. Helal, A.A. Amin and A.A. Khalifa (2002). Inhibition of methylnitrosourea (MNU) induced oxidative stress and carcinogenesis by orally administered bee honey and Nigella grains in Sprague Dawely rats, J. Exp. Clin. Cancer Res. CR. 21, 341-346.

[17] C.C. Woo, S.Y. Loo, V. Gee, C.W. Yap, G. Sethi, A.P. Kumar and K.H. Tan (2011). Anticancer activity of thymoquinone in breast cancer cells: possible involvement of PPAR-gamma pathway, Biochem. Pharmacol. 82(5), 464-475

[18] K.M. Zaman R and Akhtar MS (2004). Gastroprotective and anti-secretary effect of Nigella sativa seed and its extracts in indomethacin-treated rats, Pak. J.Biol. Sci. 7, 995-1000.

[19] U. Kalus, A. Pruss, J. Bystron, M. Jurecka, A. Smekalova, J.J. Lichius and H. Kiesewetter (2003). Effect of Nigella sativa (Black Seed) on Subjective Feeling in Patients with Allergic Diseases, Phytother. Res. 17(10), 1209-1214.

[20] M.S. Akhtar, Z. Nasir and A.R. Abid (2003). Effect of feeding powdered Nigella sativa L seeds on poultry egg production and their suitability for human consumption, Vet. Arh. 73,181-190.

[21] A. Kooshki, R. Forouzan, M.H. Rakhshani and M. Mohammadi (2016). Effect of topical application of Nigella sativa oil and oral acetaminophen on pain in elderly with knee osteoarthritis: A crossover clinical trial, Electron. Physician. 8, 3193-3197.

[22] S. Basay, N. Surmeli, G. Okcu and I. Demir (2006). Changes in germination percentages, protein and lipid contents of primed pepper seeds during storage, Acta Agric. Scand. Sect. B-Soil Plant Sci. 56, 138-142.

[23] H.S. El-Abhar, D.M. Abdallah and S. Saleh (2003). Gastroprotective activity of Nigella sativa oil and its constituent, thymoquinone, against gastric mucosal injury induced by ischaemia/reperfusion in rats, J. Ethnopharmacol. 84, 251-258.

[24] M. Farooq, S.M.A. Barsa and A. Wahid (2006). Priming of field-sown rice seed enhances germination, seedling establishment, allometry and yield, Plant Growth Regul. 49, 285-294.

[25] H. Safari, A. Tavili and M. Saberi (2010). Allelopathic effects of Thymus kotschyanus on seed germination and initial growth of Bromus tomentellus and Trifolium repens, Front. Agric. China $\mathbf{4}$, 475-480.

[26] P. Dahal and K.J. Bradford (1990). Effects of priming and endosperm integrity on seed germination rates of tomato genotypes: II Germination at reduced water potential, J. Exp. Bot. 41, 1441-1453.

[27] R.C. Styer and D.J. Cantliffe (1983). Changes in seed structure and composition during development and their effects on leakage in two endosperm mutants of sweet corn, J. Am. Soc. Hort. Sci. 108, 721-728.

[28] A. Mafakheri (2011). Effect of drought stress and subsequent recovery on protein, carbohydrate contents, catalase and peroxidase activities in three chickpea (Cicer arietinum) cultivars, Aust. J. Crop Sci. 5, 1255-1260.

[29] Y. Gursoy-Ozdemir, M. Yemisci and T. Dalkara (2012). Microvascular protection is essential for successful neuroprotection in stroke, J. Neurochem. 123, 2-11.

[30] C. Bailly, A. Benamar, F. Corbineau and D. Côme (2000). Antioxidant systems in sunflower (Helianthus annuus L) seeds as affected by priming, Seed Sci. Res.10, 35-42.

[31] P. Sharma, A.B. Jha, R.S. Dubey and M. Pessarakli (2012). Reactive oxygen species, oxidative damage, and antioxidative defense mechanism in plants under stressful conditions, J. Bot. vol. 2012, Article ID 217037, 26 pages.

[32] O.A. Ghosheh, A.A. Houdi and P.A. Crooks (1999). High performance liquid chromatographic analysis of the pharmacologically active quinones and related compounds in the oil of the black seed (Nigella sativa L.), J. Pharmaceut. Biomed. 19, 757-762.

[33] H.M. El-Fatatry (1975). Isolation and structure assignment of an antimicrobial principle from the volatile oil of Nigella sativa L. seeds, Die Pharmazie 30, 109-111. 
[34] H.Y. Aboul-Enein and L.I. Abou-Basha (1995). Simple HPLC method for the determination of thymoquinone in black seed oil (Nigella sativa Linn), J. Liq. Chromatogr. Relat. Technol. 18, 895902.

[35] M.T. Sultan, M.S. Butt, F.M. Anjum, A. Jamil, S. Akhtar and M. Nasir (2009). Nutritional profile of indigenous cultivar of black cumin seeds and antioxidant potential of its fixed and essential oil, Pak. J. Bot. 41, 1321-1330.

[36] H. Lutterodt, M. Luther, M. Slavin, J.-J. Yin, J. Parry, J.-M. Gao and L.L. Yu (2010). Fatty acid profile, thymoquinone content, oxidative stability, and antioxidant properties of cold-pressed black cumin seed oils, LWT-Food Sci. Technol. 43, 1409-1413.

[37] D. Al-Johar, N. Shinwari, J. Arif, N. Al-Sanea, A.A. Jabbar, R. El-Sayed, A. Mashhour, G. Billedo, I. El-Doush and I. Al-Saleh (2008). Role of Nigella sativa and number of its antioxidant constituents towards azoxymethane induced genotoxic effects and colon cancer in rats, Phytother. Res. Int. J. Devoted Pharmacol. Toxicol. Eval. Nat. Prod. Deriv. 22, 1311-1323.

[38] Y. Belete and E. Dagne (2014). HPTLC assay of thymoquinone in black seed and black seed oil (Nigella Sativa Linn) and identification of thymoquinone conversion with Uv-Vis, J. Drug Deliv. Ther. 4, 5-9.

[39] C.-C. Toma, G.M. Simu, D. Hanganu, N. Olah, F.M.G. Vata, C. Hammami and M. Hammami (2010). Chemical composition of the Tunisian Nigella sativa. Note I. Profile on essential oil, Farmacia 58, 458-464.

[40] S. Isik, M. Kartal and S.A. Erdem (2017). Quantitative analysis of thymoquinone in Nigella Sativa L. (black cumin) seeds and commercial seed oils and seed oil capsules from Turkey, J. Fac. Pharm. Ankara 41, 34-41.

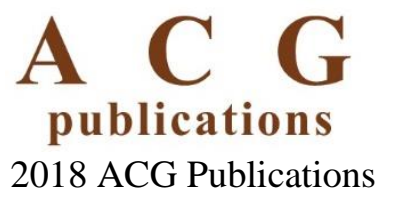

